\title{
ENVIRONMENT
}

\section{Atolls in the ocean- canaries in the mine? Australian journalism contesting climate change impacts in the Pacific}

\begin{abstract}
This article has two complementary aspects, empirical and theoretical. Empirically, it examines the reportage of the two most prolific Australian journalists on the threat posed by climate change to low-lying Pacific island states, reporting over the two-year period leading up to and following the high-profile COP15 summit in Copenhagen in 2009. It was at that summit that the concerns of the Association of Small Island States (AOSIS) were given extensive media coverage and managed to dominate the agenda for several days, to the consternation of some other summit participants. COP15 affords a good case study because the media coverage of this issue was variegated and heavily contested, contrary to earlier scholarly claims about an allegedly mono-dimensional quality to the journalism about climate change in the Pacific Ocean (Nash \& Bacon, 2013). The two journalists were Adam Morton, environment reporter for The Age newspaper in Melbourne, and Rowan Callick, Asia-Pacific editor for The Australian, who produced ten and seven distinct reports respectively on this issue over the period, and took more or less contrary positions on the validity of the threat claims. Theoretically, the article argues firstly, and following Tuchman (1978), that spatio-temporality is a defining dimension of journalistic research and reportage, and it extends Tuchman by drawing on the work of David Harvey $(1973,2006)$ and Henri Lefebvre (1991) to analyse and compare the spatio-temporal dimensions of the reportage by the two journalists. Secondly, it argues that the successful application of scholarly debates about spatio-temporality to journalism practice supports the contention that some journalism can and should be treated as scholarly research practice alongside other humanities and social sciences (Nash 2013, 2014).
\end{abstract}

Keywords: balance, climate change, environmental journalism, fairness, field analysis, global warming, journalism as research, small island states, The Age, The Australian

Chris Nash

Monash University, Melbourne

PACIFIC JOURNALISM REVIEW 21 (1) 201579 
N LATE March, 2014 the Intergovernmental Panel on Climate Change (IPCC) released the Summary for Policymakers (IPCC, 2014a) of its 32-volume 2014 report (IPCC, 2014), the fifth in the series since the first in 1990 and the fourth in 2007. For the launch, various scientist co-authors were quoted in the press making statements such as '[t]hings are worse than we had predicted [in 2007]', '[w]e are going to see more and more impacts, faster and sooner than we had anticipated' and ' $\mathrm{t}]$ he horrible is something quite likely, and we won't be able to do anything about it,' (Al-Jazeera, 2014). The 2014 report will provide the scientific context for the discussion by world leaders at the COP21 (formally, the Conference of the Parties) summit scheduled for Paris in December 2015. Expectations are building that the COP21 conference will achieve much more than the last climate change summit event attended by major world leaders, the 2009 COP15 Conference in Copenhagen.

The COP15 summit was notable for several things: firstly, the way in which the Association of Small Island States led by Tuvalu was able to commandeer the conference proceedings and highlight the plight of some of its members as the vulnerable first rank of countries set to become uninhabitable, if not disappear altogether, as a consequence of human-induced climate change; secondly, the undisguised policy discord between China and the US as major international generators of greenhouse gas emissions; thirdly, the ineffectiveness and apparent irrelevance of European attempts at conference leadership on effective policy development; and fourthly, the abject failure of the participating national governments to agree on much more than face-saving deferrals and procrastination on policy responses. For an introductory outline of the key events and outcomes at COP15 the UNFCCC website provides the official account (UNFCC, 2009), while Ryan addresses the Pacific Island perspective (Ryan, 2010).

There was a huge global media focus on climate change in the lead-up to and during COP15. In Australia, no other issue had more coverage in 2009 (Chubb \& Bacon, 2010). Australian journalism about the impact of climate change on Pacific Island states was similarly intensive, and thus provided a large empirical data set for analysis on this issue. Nash and Bacon (2013) examined the content of ten major Australian newspapers and ABC News and ABC Current Affairs programmes on radio and television, generating a total of 282 individual reports, over the period from 1 October 2009 to 30 November 2011. They found that the journalism was variegated and heavily contested, contrary to earlier scholarly claims (Connell, 2003; Farbotko, 2005, 2010a, 2010b; Farbotko and Macgregor, 2010; Cameron, 2011). The results of their research were summarised as follows:

Contrary to a prominent observation in the social sciences literature, Australian media coverage of climate change with respect to small island states is neither monolithic nor bipolar, but deeply variegated by multiple factors including spatiality, temporality, genre, attitude towards climate science and the use of sources. It cannot be readily reduced to single or binary categories. This variegation is not random but

80 PACIFIC JOURNALISM REVIEW 21(1) 2015 
deeply structured by the factors listed, and this complex structure constitutes the dynamic field of media reporting on this issue within which participants act. What is striking about the reporting is the extent to which it is contested within the field ... 17 percent of reporting does not take an implicit or explicit stance in respect of the fundamental question of whether climate change poses a threat to small island states, which means that conversely, more than four-fifths of the reporting does take such a stance. (Nash \& Bacon, 2013, p. 256)

That research detailed the structure of the contested field of Australian reporting on this topic over the specified period. Within the coverage, the most prolific journalists were Adam Morton, environment reporter for The Age newspaper, who produced ten distinct reports, and Rowan Callick, Asia-Pacific editor for The Australian newspaper, with seven stories over the period. The Age is based in Melbourne while The Australian is a national newspaper; both are targeted at affluent, educated readerships; the Fairfaxowned Age is widely regarded as the most liberal mainstream newspaper in its social orientation while the News Corp-owned Australian is oriented to a right-wing political and business audience. This current article seeks to add depth to the field analysis by examining in specific detail the research and reporting practice of these two leading journalists, who conveniently took contrary positions on anthropogenic climate change, Morton strongly endorsing the scientific consensus and Callick offering a confusing interpretation.

In what follows, I will firstly outline the theoretical framework I will use for the analysis, then give an account of the coverage by the two reporters and analyse the adequacy of their research and reporting practice with respect to the truth claims they make, and finally indicate the significance of this analysis for the standing of journalism as a research practice among the humanities and social sciences.

\section{Theoretical framework}

The adequacy of research practice is a methodological question. Methodologies need to be detailed and intellectually rigorous, produce verifiable truth claims and go well beyond the basic journalistic touchstones of 'fairness' and 'balance'. Methodologies derive from conceptual frameworks, and there is an issue, discussed elsewhere (Nash 2013, 2014, 2015 forthcoming), about whether journalism is a disciplinary or intellectual activity, as distinct from a craft. This author agrees with Gaye Tuchman that journalism is a 'theoretic' activity and '[f]urthermore, news stories engage in theorising by juxtaposing facts gleaned from sources. Juxtaposition is a form of categorising, since it encourages the understanding that these facts have something to do with one another. It both claims and creates a theoretic relationship between and among the phenomena presented as facts' (Tuchman, 1978, p. 204). Facts for journalists are 'pertinent information gathered by professionally validated methods specifying the relationship between what 
POLITICAL JOURNALISM IN THE ASIA-PACIFIC

is known and how it is known' (Tuchman, 1978, p. 82), which is a precise statement of the methodological requirement for valid truth claims.

Tuchman argues that journalistic research involves the production of a 'web of facticity' in space and time, i.e. journalists prioritise their actions in space and time to include certain opportunities for observation and evidence-gathering and to preclude others (Tuchman, 1978, pp. 82ff). She puts the spatio-temporality of their research practice at the very crux of their 'professionally validated methods [for] specifying the relationship between what is known and how it is known'. However, she treats space and time as self-evident and unproblematic concepts, which limits their efficacy for analytical purposes. Harvey and Lefebvre would concur with Tuchman on the fundamental importance of spatio-temporality in all human activity, but they separately propose much more multi-dimensional conceptualisations, which offer a richer framework for analysing the validity of truth claims.

David Harvey in 1973 (Harvey, 2009 [1973]) proposed a tri-dimensional framework for the conceptualisation of space: absolute, relative and relational space. Absolute space does not include time, and is stable, available to physical apprehension through the senses, and its attributes are directly measurable and verifiable; in short, it is the stable physical environment as we experience it. Relative space incorporates time, and therefore activity, change and movement, i.e. process. It involves the movement and circulation of mass and/or energy and therefore includes phenomena such as transportation, communication, markets, electronic and magnetic activity, weather activity, growth, decay and destruction. It is also directly observable and measurable. Relational space is constituted by the relations between agents or forces that produce the processes of relative space and the spatial characteristics of absolute space, for example the positive and negative poles of electric fields that produce electric currents and effects, differences in atmospheric density that produce weather patterns and events, demand and supply that produce exchange value and therefore prices and transactions in a market. Relational space is where values reside (Harvey, 2006, p. 141), and importantly it is not directly observable or measureable except through the facts it produces in absolute space, e.g. a weather event, a business meeting, and/or the processes it produces in relative space. Thus economic demand for a commodity is not measurable until it becomes active in relation to supply and produces a price in a market, social power is not evident until it produces activity that would not have otherwise occurred, and so on.

Harvey argues that relational space incorporates relative and absolute space, relative space incorporates absolute space, and absolute space does not incorporate either of the other two dimensions, although he very specifically states that there is no hierarchy among the three dimensions, that all three dimensions are potentially present in any spatial situation, and the key issue is how 'different human practices create and make use of different conceptualisations of space' (Harvey, 2006, pp. 125-6).

82 PACIFIC JOURNALISM REVIEW 21(1) 2015 
Harvey was theorising space as it exists prior to any given act of human agency. Henri Lefebvre was interested in the social production of space $(1991$ [1974, 1984]). His conceptualisation is also tri-dimensional, encompassing material space, the representation of space and spaces of representation, or to put more prosaically-perceived space, conceived space and lived space (Lefebvre, 1991, pp. 38-41). Perceived space is amenable to direct and measurable human experience through the five senses; conceived space is a logical framework for understanding space, eg Euclidean geometry, Newtonian physics, climatology, political theory, economic theory; and lived space encompasses emotions, imagination, culture and so forth.

In 2006, Harvey reaffirmed his own theorisation of spatio-temporality, and put it together with Lefebvre's theorisation of the spatiality of social practice to produce a matrix (Harvey, 2006, p. 135). He made no greater claims for this matrix than the thought it might be interesting as a conceptual tool to make sure that the complexity and nuance of human interaction with the spatial environment was being captured in any analysis. He did not advocate its use as a rigid checklist, but as a scoping tool. The theoretical aim of this article is to test whether the Harvey-Lefebvre matrix is a useful methodological tool for the evaluation of journalistic research practice. I have argued elsewhere (Nash, 2015, forthcoming) that news value is located in relational space because value is a relational concept - it does not exist except as a relationship between agents - and news is always about the value attached to change (in relative space) as evidenced by the facts (phenomena in absolute space) and its implications for relational space (how would/should agents reposition themselves to adjust to the reported change), sometimes very specifically conceived as in the import of a political decision by government, and sometimes very broadly conceived, e.g. the human condition in a 'human interest' story. Therefore news values are necessarily vague and indeterminate because they are not observable and measureable. Journalists in their practice produce evidence from absolute and relative space ('facts' that are verifiable, e.g. a politician's statement or a car accident) to support their analyses of the significance or meaning of the situation in relational space (values that are not verifiable), and therefore there is always contestable terrain between the production of verifiable empirical evidence and the consequent production of meaning.

In Lefebvre's terms, journalists act in perceived space to produce verifiable evidence in their reports; they assemble that evidence according to a logic that should demonstrate some consistency and validity in conceived space; and it is usually written with an eye for the lived space of the news consumer in the hope that it will appeal to their emotions, imagination and cultural sympathies. Table 1 sets out my interpretation of the HarveyLefebvre matrix for the purposes of journalism.

Before moving to the analysis of Morton's and Callick's journalism, I will rephrase and recapitulate the argument in favour of testing this theoretical framework in the ensuing analysis. Journalists report factual evidence for the truth claims they make in their reportage, and those facts need to be locatable in space and time for verification purposes.

PACIFIC JOURNALISM REVIEW 21 (1) 201583 
POLITICAL JOURNALISM IN THE ASIA-PACIFIC

Table 1: The Harvey-Lefebvre matrix as applied to journalism
\begin{tabular}{|l|l|l|l|}
\hline \multicolumn{1}{|c|}{ Perceived space } & \multicolumn{1}{c|}{ Conceived space } & \multicolumn{1}{c|}{ Lived space } \\
\hline Absolute space & observable facts & $\begin{array}{l}\text { logical framework for } \\
\text { identifying facts }\end{array}$ & $\begin{array}{l}\text { IEC engagement with } \\
\text { facts }\end{array}$ \\
\hline Relative space & $\begin{array}{l}\text { observable processes } \\
\text { producing outcomes }\end{array}$ & $\begin{array}{l}\text { logical framework } \\
\text { for apprehending } \\
\text { processes }\end{array}$ & $\begin{array}{l}\text { IEC engagement with } \\
\text { processes }\end{array}$ \\
\hline Relational space & $\begin{array}{l}\text { invisible values and } \\
\text { forces at work to } \\
\text { produce processes } \\
\text { and outcomes }\end{array}$ & $\begin{array}{l}\text { logical framework for } \\
\text { apprehending relation- } \\
\text { ship of forces and values }\end{array}$ & $\begin{array}{l}\text { IEC engagement with } \\
\text { relationships and } \\
\text { values }\end{array}$ \\
\hline
\end{tabular}

Note: IEC - imaginative, emotional, cultural etc.

Therefore the activity of journalists in space and time to include or exclude various facts in a report is a fundamental characteristic of the "professionally validated methods specifying the relationship between what is known and how it is known' (Tuchman, 1978, p. 82). However, the news value of facts is not self-evident, and those facts need to be located in processes of change and development in a story (i.e. what's new?) that signify shifts in the continually developing relationships that underpin and drive the processes. Therefore, for analytical purposes we need a conceptualisation of the spatio-temporality within which journalists operate that can identify facts for verification purposes, but locate them within processes of change (and therefore incorporate time) and provide evidence for truth claims about the underlying values and relations that are driving the process. What is more, when journalists research and produce a report, they are working within an environment that has experiential, conceptual and imaginative/ emotional/ cultural characteristics, and their reports will be consumed and meaning produced by audiences/ readerships in circumstances that have specific experiential, conceptual and imaginative/emotional/cultural characteristics. Harvey and Lefebvre separately and together have theorised spatio-temporality with this degree of complexity, and our task now is to test its validity and utility in an empirical analysis. I would also note in passing that this methodology is compatible with a broadly Bourdieusian field analysis. Bourdieu's field theory provides a relational spatial metaphor for analysing social practice (Bourdieu 1977, 1990), and it complements, and indeed requires, a theorisation of spatiality (for instance, per Harvey and Lefebvre) to make it amenable to empirical research.

\section{The reportage}

Adam Morton produced ten reports (Table 2) on climate change in the Pacific for The Age (with two repeats in the $S M H$ ), among many other reports on climate change, COP15 and the state of the environment more broadly over the period. The average word length was 957 words. One, the second longest at 1726 words, was written from

84 PACIFIC JOURNALISM REVIEW 21(1) 2015 
POLITICAL JOURNALISM IN THE ASIA-PACIFIC

Table 2: The Adam Morton reportage for The Age, 2009-2010
\begin{tabular}{|l|l|l|l|}
\hline Date & Words & Location & Headline \\
\hline $21 / 11 / 09$ & 1726 & Kiribati & As the globe warms up, a way of life is washed away \\
\hline $21 / 11 / 09$ & 1369 & Kiribati & Land of the rising sea (SMH edited repeat) \\
\hline $8 / 12 / 09$ & 510 & Copenhagen & Copenhagen deal within reach, says climate talks host \\
\hline $11 / 12 / 09$ & 595 & Copenhagen & Small nation with big voice and bigger problem \\
\hline $14 / 12 / 09$ & 568 & Copenhagen & Wanted (badly): US and China to get along \\
\hline $16 / 12 / 09$ & 370 & Copenhagen & Rich-poor divide theatens real deal \\
\hline $16 / 12 / 09$ & 613 & Copenhagen & Uneasy truce between wealthy and poor nations \\
\hline $18 / 12 / 09$ & 584 & Copenhagen & Breakaway nations rebel against China \\
\hline $18 / 12 / 09$ & 611 & Copenhagen & $\begin{array}{l}\text { History will judge us if we fail, says Rudd, Clinton turns } \\
\text { up heat on China }\end{array}$ \\
\hline $19 / 12 / 09$ & 617 & Copenhagen & The science is clear, but the politics are murky \\
\hline $27 / 3 / 10$ & 2150 & Melbourne & Climate can-do in Cancun? \\
\hline $27 / 3 / 10$ & 1777 & Melbourne & Copenhagen makes a comeback (SMH edited repeat) \\
\hline
\end{tabular}

Kiribati the month before COP 15, eight from the conference in Copenhagen, and the longest article (2150 words) as a reappraisal of the conference outcomes about three months after the event.

In anticipation of the looming prominence of the Pacific Islands at the conference, he visited Kiribati in the month before it began. He began his feature article thus:

When a coconut tree dies, the decay starts at the top. First the leaves fall, then the fruit. All that is left is a desiccated trunk, cut off at half-mast. In a low-lying area flooded with seawater, the dead palms look like natural tidal gauges, the high water mark visible on their stranded remains. There is no shortage of them in Tebunginako, a tiny village on an outer island of the Pacific republic of Kiribati (pronounced Kiribas). (Morton, 2009a)

In the article, Morton referred to an array of direct evidence including dying trees, housing ruins now located offshore, quoted interviews with a range of sources including Kiribati and Australian politicians and local villagers, rising tidal levels surrounding buildings, reports from the World Bank and the Australian National Tidal Centre and the decline/disappearance of named fish and plant species. He cited natural processes including climate change, changing weather patterns, changing sea levels, environmental degradation and changing/disappearing landscape, and social processes including political debate and policy development at the local level, translocation of living quarters, changing food production practices and participation in international policy development processes. Throughout the article the locals are presented in relation to 
POLITICAL JOURNALISM IN THE ASIA-PACIFIC

each other as a functioning polity, society and culture, and in relation to the international arena as participants of environmental and social processes beyond their control that they are attempting to mitigate, adapt to and/or participate in by adopting various roles.

The following eight articles by Morton were sourced from the COP15 summit in Copenhagen, and they described events, statements and actions by participants in the conference. A key figure in his reports was Ian Fry, whom he described in an early report on December 11 as a '56-year-old former environmental campaigner' who, as the official representative of the Tuvalu government, had called on the conference to create two treaties - one for industrialised countries and one for other countries - and for global warming to be limited to 1.5 degrees. Tuvalu's move was supported by other island nations and some other poorer countries that were angry that China, India and other nations had blocked the proposal. Fry was the defining and most important source in this article, which ended with Australian Climate Change Minister Penny Wong admitting that the talks had not begun well (Morton, 2009b).

The following day, Morton reported that the small island states had delayed proceedings for two days, providing justification for their claim with a reference to scientific findings that any limit higher than 1.5 degrees would 'lead to disastrous damage from rising sea levels and extreme weather'. He quoted Desmina Williams, a Grenada diplomat and spokesperson for the Small Islands Alliance, who pleaded with the conference to accept evidence that 'our islands are disappearing, our corals are bleaching, we are losing our fish supplies' (Morton, 2009c). On December 13, Morton again referred to Fry, who had been in tears when he made a 'strong and impassioned plea' for a 'deal rather than a decision to delay a legally binding treaty until next year'. He described Fry as fighting for the 'human rights of a country predicted to be among the first victims of climate change' (Morton, 2009d). In an article the following day that mostly focussed on the role in negotiations of China and the US, Morton described Ian Fry as 'for many the hero of the summit for his valiant fight' (Morton, 2009e). In yet another article, Morton referred to players as 'crudely divided up into heroes, villains and those with intentions which are harder to decode', and he again referred to Fry as the 'chief hero' whose 'principles were pure' (Morton, 2009f).

On the final evening of COP15, Morton reported that the conference 'ended in chaos after a small number of developing nations rejected a last-minute backroom deal between the world's biggest emitters and announced by US President Barack Obama'. After quoting a number of sources, including Obama and then-Australian Prime Minister Kevin Rudd, he focused on those who had rejected the deal including Tuvalu, quoting Ian Fry as arguing that the deal would 'lead to the tiny country being inundated by rising seas .... In biblical terms it looks like we are being offered 30 pieces of silver to betray our future and our people ... our future is not for sale' (Morton 2009g).

A key theme in Morton's reporting from Copenhagen was the role played by small countries, especially Tuvalu, in the framework of geopolitical negotiations. The tone of

86 PACIFIC JOURNALISM REVIEW 21(1) 2015 
his reports was earnest and serious. Quoted sources were described in respectful terms, including when Morton would appear to be disapproving of their stated position. His underlying premise was that dissenting small developing countries had a just cause in resisting the deal struck by more powerful geopolitical players. He retained a steady focus on them as active players intervening in the conference proceedings, not merely to garner worldwide attention for their plight but to influence the outcome. Although Morton expressed the opinion that Fry may have held up proceedings for too long, he nevertheless portrayed him as a legitimate player who had earned the respect of many (Morton 2009e). This contrasted with other reports, including in The Australian, that mocked Fry as not affected by sea-level rises because his home in Canberra was 144 kilometres from the coast (McIntosh, 2009; Maiden, 2009).

Three months after Copenhagen, Morton wrote a long analytical article in which he reviewed the geopolitical situation in the aftermath of COP 15 and the lead-up to the COP16 conference to be held in Cancun, Mexico in December 2010. The thrust of the article was that the climate change threat was serious, but that the achievements of COP15 were greater than generally acknowledged at the time by commentators. He expressed some optimism for future action by governments (Morton, 2010). During the period of our study, Morton published no other articles referring to small island states in the context of climate change.

The Australian's Asia Pacific editor Rowan Callick wrote seven articles (Table 3) in our sample, making a major contribution to the paper's coverage of climate change in the Pacific during this period. The average word length was 1138 words. His articles were spread out across the whole two-year period of the sample, contrasting with Morton's focus on the COP 15 summit. All of them were written from his office in Australia.

The first article was written during COP15 and began, 'Pacific island nations are under threat from a great deal more than global warming' and focused on Leah Wickham, 'a banker' and 'Suva-based Greenpeace activist' from Fiji who told the opening session of the conference that as someone on the 'frontlines of climate change' she 'hoped that

Table 3: The Rowan Callick reportage file for The Australian, 2009-2010

\begin{tabular}{|l|l|l|l|}
\hline Date & Words & Location & Headline \\
\hline $12 / 12 / 09$ & 1378 & Australia & Strange climate neglect \\
\hline $2 / 1 / 10$ & 1533 & Australia & Movement for progress gets stuck in the lobby \\
\hline $4 / 6 / 10$ & 466 & Australia & Pacific Islands 'growing, not sinking' \\
\hline $11 / 6 / 10$ & 2046 & Australia & Coral islands left high and dry \\
\hline $18 / 12 / 10$ & 409 & Australia & Sinking islanders await rescue \\
\hline $22 / 7 / 11$ & 487 & Australia & UN snubs pleas on climate change \\
\hline $5 / 9 / 11$ & 1646 & Australia & Fiji casts shadow on Pacific forum \\
\hline
\end{tabular}


POLITICAL JOURNALISM IN THE ASIA-PACIFIC

her children would still be able to call our beautiful islands home'. After acknowledging her statement that 'scientists' are saying that 'low-lying islands such as Fiji are vulnerable to rising sea levels', he commented '[t]hey must be some scientists' (Callick, 2009).

Callick invited his readers to visit Nadi airport where they would see mountains of more than 1000 metres and referred to Australian National Tidal Centre research which showed Fijian sea levels are rising at $5.3 \mathrm{~mm}$ a year, which he concluded meant that Wickham's fears for children were ill-founded. He acknowledged that 'evidence of the effect of climate change' in Kiribati was of 'greater concern' but asserted that if people relied on COP15 to deliver hope, they risked 'moving back to a form of cargo cult reliance on remote mechanisms, on the generosity or guilt feelings of foreigners (Callick, 2009). Contrary to the 'cargo cult' allegation, there is extensive research documenting the intense activity by AOSIS governments in response to the climate change challenges (Barnett and Campbell, 2010, pp. 111-137).

Callick quoted individual spokespeople for organisations from various international bodies and nations, referred to a range of academic and government reports as evidence; cited rubbish in waterways, inappropriate construction and large families as alternative environmental factors; queried the assumptions behind some computer modelling of rising sea levels, and cited "a vast range of factors to be considered in assessing the reason for changing sea levels: tectonic plate movement, the removal of groundwater because of excess populations, mining sand for construction, the removal of vegetation, El Niño and La Niña, and what the tidal centre calls a decadal slosh." (Callick, 2009) In terms of social processes he described and cited 'cargo cults' as a dangerous factor, and asserted that " $[\mathrm{t}]$ he next biggest danger in the islands region, after climate change, is the reorienting of environmental efforts, of development plans, of the process of government, towards this [Copenhagen] process". He decried aid dependency, endemic corruption, government unaccountability and a generalised lack of responsibility: "talking in Copenhagen is unlikely to deliver a significant improvement in island environments. Responsibility for that still lies substantially within the grasp of islanders themselves and their constantly globetrotting government leaders" (Callick, 2009).

This was Callick's only report during the COP15 conference itself, but there was a steady stream of articles over the next two years that referred to the issue, notably when two scientists published research suggesting that some islands at least were growing and not shrinking. Callick's attribution of authority to this research needs to be put into a wider context. In May 2010, the peer-reviewed journal Global and Planetary Change published a study by Drs Arthur Webb (Applied Geoscience Commission, Fiji) and Paul Kench (Auckland University) which used aerial photography and satellite images to study 27 low-lying Pacific atolls, and concluded that despite sea level rise and erosion, 86 percent of the islands had remained stable or increased in size due to accretion in other parts of the atolls, while the rest declined in size (Kench \& Webb, 2010). This report built on earlier published work by these two scientists. Two weeks later it was picked up and

88 PACIFIC JOURNALISM REVIEW 21(1) 2015 
promoted by New Scientist (McDonald, 2009).

On June 4, The Australian published a news story (406 words) by Callick about the research report that quoted no researchers other than Kench and Webb. He quoted Kench in the New Scientist: 'It has been thought that as the sea level goes up, islands will sit there and drown. But they won't. The sea levels will go up and the island will start responding.' Callick's story conveyed the imputation that sea level rise was not likely to be as serious a problem in the Pacific as previously understood (Callick, 2010).

The Kench and Webb research is well-known among climatologists, and controversial not because of its own specific findings but because it can be easily taken out of context to support unwarranted conclusions (Leslie, 2004; Woodruffe, 2008; Schaefer \& Hare, 2010.) The ABC broadcast a report the day before Callick's report in which reporter Phillipa McDonald contextualised the Kench and Webb results within broader scientific interpretations (McDonald, 2010). Similarly the Pacific newsagency Pacnews, which had issued a short story about the research the week before, published a second report by Pacific Islands reporter Makereta Komai quoting Solomon Islands Ambassador Beck in Germany who described it as 'politicised science' (Komai, 2010).

Three days later, Callick wrote a further 2046 words on the Webb and Kench study. This article had a more detailed account of the research but quoted no other scientists or other critics of the study. The article began:

The globetrotting leaders of Pacific islands who have attained international celebrity - especially in Europe - over the slow drowning of their homelands, are in a state of shock. The latest research indicates that most of the Pacific's low-lying islands are growing, not shrinking. And this week leaders of Tuvalu and Kiribati, the nations most often cited as the victims of inundation, struggled to respond to these findings: good news for their countrymen but an awkward message for those who have feted them as victims. (Callick, 2010b)

No evidence was provided that either Kiribati's President Anote Tong or Tuvalu Prime Minister Apisai Ielemi were in a 'state of shock'. Callick quoted a Kiribati spokesperson to the effect that some islands had causeways and other constructions that could provide an explanation for shifting shorelines, but that this might not apply to other islands.

\section{Analysis}

Harvey suggested that his matrix should be used in ways that are 'suggestive rather than definitive .... [I]t is possible to think dialectically across the elements within the matrix so that each moment is imagined as an internal relation of all the others' (Harvey, 2006, p. 134). While agreeing with that approach, in what follows I have named and treated each of the elements in the matrix separately, moving vertically down each column in turn, in order to see with some specificity what the method reveals about the reportage. 
POLITICAL JOURNALISM IN THE ASIA-PACIFIC

The potential for dialectical links among the elements quickly becomes clear, but their identification and analysis would depend upon particular theoretical frameworks. The following analysis is operating at the meta-theoretical level, to argue the case for the potential and need for subsequent analysis within identified theoretical frameworks.

\section{Perceived-Absolute space}

Morton's reporting entailed personal observation in Kiribati or Copenhagen in all but one story. He gave factually detailed and internally consistent accounts of the different situations from which he was reporting, and used a wide range of sources including government and NGO spokespeople, official documents, community leaders and NGOs.

Callick's reports were all sourced from his Australian office, though he would have been drawing on his extensive personal experience in the Pacific region. He did cite factual accounts of particular events using other reports, including speeches by Leah Wickham and Ian Fry, and did cite material facts such as the height of Fiji mountains, the home address of Ian Fry in Queanbeyan, Australia, and the report findings by Kench and Webb. His reports also cited unspecified physical facts such as large families, rubbish and shifting coral detritus.

\section{Perceived-Relative space}

Morton provided accounts and evidence of various processes, e.g. changing climate patterns, the scientific research into climate change under UNFCCC's aegis, the diplomatic process at Copenhagen and other national and international governmental forums and processes. He accepted the legitimacy and bona fides of these processes, explored their complexities, and used the evidence he was reporting, whether it was in agreement or disagreement, to encourage a perception that the COP 15 process was very serious.

Callick provided material evidence, such as the height of Fiji mountains or Fry's home address, to dispute the relevance or bona fides of individuals and organisations participating in the COP 15 negotiations. While acknowledging the reality of climate change he cited various scientific research and alternative factors to query its applicability or the seriousness of its consequences in given situations. He disputed the integrity and capacity of governments in dealing with the issue, dismissed the utility of international governmental processes in addressing climate change, and generally favoured local action and self-help as the most efficacious response. He ridiculed the COP process.

\section{Perceived-Relational space}

Morton used a wide range of official and local sources to nominate and describe the 'players' in both the climatic processes and the social ones. He described in detail the evidence supporting their relational position to the issues and processes and their dialectical activities in those processes. He accepted the AOSIS and scientific claims that the Pacific islands were in a frontline relationship to climate change impacts, and he described the values that the small island inhabitants and governments were invoking to position themselves in response to the challenges and processes underway.

90 PACIFIC JOURNALISM REVIEW 21(1) 2015 
Callick acknowledged the underlying process of climate change, but sought to dispute the integrity and capability of some participants in relation to the COP process, gave a partial and decontextualised account of the value of the Kench and Webb research in relation to other research, challenged the relevance of governmental and international responses to the process of climate change mitigation and adaptation, and generally alleged that the supposed crisis was a product of manipulation by activists and incompetence of governments and UN bodies.

\section{Conceived-Absolute space}

Morton's selection of evidence and the factual accounts in his reportage accorded with the conceptual frame of the scientific consensus on anthropogenic climate change. The content and focus in his reports, and the fact that his first major report on this topic resulted from travel to remote Kiribati, provided evidence in support of the early impact of global climate change on the small island states. His Copenhagen reportage accepted the conceptual framework of coordinated governmental intervention as an appropriate response to the challenges.

Callick's articles were ambiguous and ambivalent with respect to the climate science consensus on anthropogenic climate change. He was dismissive of the utility of the COP process, and cited irrelevant facts (Fiji's mountains, Fry's home address) to query the integrity of the process. While claiming to accept the analysis, he queried or denied its applications to specific physical environments, and cited allegedly contrary evidence such as the Kench and Webb research. Twice he characterised islander responses to the issue as 'cargo cults', thus presenting an arguably colonialist conceptual framework to disparage local responses (for early and more recent interrogations of the usage of the term 'cargo cult' see Pouwer, 1958; and Kaplan, 1995)

\section{Conceived-Relative space}

Morton clearly accepted the relevance and integrity of the scientific and diplomatic processes in train under the aegis of the UNFCCC. Within that frame he further accepted the specific arguments by AOSIS about their members' place in those natural and social processes. He didn't query the need for internationally co-ordinated government processes, and indeed was critical of both individuals (Fry) and governments (eg China) that he perceived to be inhibiting the progress of negotiations.

Callick, while avowedly accepting the scientific consensus, cited other unrelated processes (tectonic plate movements, over-population, mining) as commensurate and responsible for some predicted climate change impacts, which arguably confused the conceptual picture rather than enhancing it. He accepted the Kench and Webb research but ostensibly misinterpreted it and failed to locate it within the larger scientific discussion as other journalists did. Most importantly, he explicitly argued that the two processes of effective climate change-adaptation and mitigation on the one hand and coordinated governmental responses on the other-were antithetical to each other. He argued that 
POLITICAL JOURNALISM IN THE ASIA-PACIFIC

the most appropriate social process was self-help and hard work by islanders at the local level. There is a logical incompatibility between the global scale of the problems and solely local scale of the proposed solutions, which Callick did not address.

Conceived-Relational space

Morton approved of the values and position taken by AOSIS in response to their experience of climate change impacts, and in their diplomatic endeavours, though he did query the utility of the two-day hiatus in COP15 negotiations precipitated by Ian Fry. He effectively endorsed the appropriateness for AOSIS members of diplomatic fora such as COP and also local government and community processes such as the development of renewable energy sources, property purchases on unthreatened islands such as Fiji and guest worker arrangements with Australia and New Zealand to allow families to raise funds for such activities.

Callick disputed outright the relevance and effectiveness for island nations to enter into relations with international diplomatic negotiators on this issue. He argued that the island populations were being poorly served by their political leaderships and by international NGOs. He was dismissive of the positions being taken by international agencies, some scientists and the diplomatic community with respect to the challenges of climate change, and recommended that the islanders take a simple approach based on self-help, because all other avenues at the national and international levels were effectively incompetent and/or disingenuous.

Lived-Absolute space

Morton's accounts and language in depicting life on Kiribati and the lived experience of the Copenhagen conference included emotive terms of frustration, anger, despair and hope. He was empathetic with the perceived plight of island populations, their leaders and the NGOs and governments seeking to achieve effective responses at the summit. His reports from Kiribati were able to depict an imagined future experience of severe environmental degradation, translocation or emigration and their social and personal consequences.

Callick viewed such anxiety and fear as misplaced, expressed anger and contempt for Western activists and what he viewed as incompetent and irresponsible leaders, and described its effect as a 'cargo cult' passivity among island peoples. His description of Wickham's and Fry's activities and speeches at Copenhagen was contemptuous; arguably he was expressing frustration at an alleged unwillingness and incapacity of the island peoples for self-help and hard work, and despair at its likely consequences.

\section{Lived-Relative space}

Morton depicted the Kiribati experience and the COP processes as very serious and earnest in their efforts, but COP in particular became 'theatre' with its 'heroes and villains'. As the COP summit proceeded, he came to describe the process in tragic and occasionally farcical terms as it developed towards the final communiqué.

92 PACIFIC JOURNALISM REVIEW 21(1) 2015 
Callick depicted the COP process, and international diplomatic processes on this issue in general, as farcical and disingenuous. He depicted shock and consternation (allegedly, and perhaps hyperbolically) among island leaders in response to the Kench and Webb research, and a general inability by island leaderships to engage constructively with the processes affecting their citizenry.

\section{Lived-Relational space}

Morton accepted the AOSIS view of their status and standing in relation to the issues and the negotiations at COP. He depicted Tuvalu and the Maldives as the leading AOSIS participants, gave them equal moral standing compared to larger states on the geopolitics of the issues, and described Fry as a perhaps flawed 'hero' in the 'theatre' of the convention. The AOSIS representatives were depicted as active, intelligent and effective, and as equal to Western government representatives in their competence and capacities. Morton was willing to align the interpretation of the conference proceedings with the perspectives and emotions of the AOSIS representatives, and accepted their characterization that they were the undeserved victims of anthropogenic climate change precipitated by large industrial economies. But they were depicted not as mendicants but as frontline representatives of a common humanity for whom the climate change bell is tolling.

Callick evinced an ill-disguised contempt for most of the participants in the climate change issue - disingenuous Western activists, incompetent island leaderships, misconceived scientists, passive islanders. He represented the international process as largely farcical, and mocked the positions taken by individuals such as Wickham and Fry at Copenhagen and 'shocked' island leaders in response to contrary scientific evidence. He bemoaned the impact of 'cargo cult' attitudes on unsuspecting island peoples being incompetently led by their elected representatives and western activists. Arguably Callick's depiction was underpinned by a genuine concern for the plight of island peoples in the face of such alleged incompetence and duplicity.

\section{Discussion}

The detail of the analysis above, as the successive elements or boxes of the matrix are filled in, confirms Harvey's point that the framework should be used suggestively and dialectically with respect to the internal relations among the different categories. There are many cross-connections, as indeed there must be: the different dimensions in the vertical and horizontal axes, Harvey's and Lefebvre's respectively, are themselves intertwined. But that is not to say that there aren't clear differences that emerge in the spatio-temporality of the two journalists' practice.

Callick as an editor was reporting from his Australian office, whereas Morton produced only one of his ten reports (the last one) from the office, and for the others he travelled to Kiribati and Copenhagen. Morton's visit to Kiribati enabled him to confirm 
POLITICAL JOURNALISM IN THE ASIA-PACIFIC

evidence through personal observation, and interview a range of local sources to produce a detailed and nuanced analysis, while Callick, albeit perhaps drawing upon previous and lengthy personal experience or second-hand reports, reduced the analysis to the generalised characterisation of contradictory science, leadership incompetence, manipulation by activists and cargo-cult passivity among the populace. Morton's disposition in absolute space at Copenhagen enabled him to report firsthand on the material facts of interviews, speeches, documents and discussion as he personally observed them, the processes as they developed and the shifting relations among the players as they responded to the developments. Callick was forced to rely on others' reports from the conference, which information he then used in a different context, e.g. in his scepticism about the roles of Wickham and Fry. The two reporters conceptualised Fry's role in radically different ways: Morton reported him as a popular hero among a section of the attendees, whereas for Callick he was an impostor because he was not indigenous and lived in the suburbs of Canberra. In terms of lived or imagined space, for Morton the conference became tragic theatre, whereas for Callick it was disreputable farce. The conference process for Morton was conceptualised as a valid exercise in diplomacy and policy development, whereas for Callick its avowed aims were invalid and in practice it was directly antithetical to the interests of the Pacific Island peoples.

Generally it might be said that Morton conceptualised the scientific consensus on the climatology, and the international diplomacy, as bona fide activities in all his reports, and those bona fides formed the foundation for the sympathetic lived or emotional dimension of his accounts as the processes unfolded in his presence at the different locations. For Callick it was the alleged lack of bona fides in both the reported science and the diplomacy that justified the cynical and alienated emotional dimension, although arguably the relationship flowed the other way - it was a jaundiced, perhaps despairing emotional response that prompted the conceptual alienation from the science and the diplomacy.

The matrix framework can be applied almost on a fact-by-fact basis in an analysis like this, simply by posing questions such as: By what process does this particular fact get produced? What are the relations among agents or players in this field that are driving the process to produce these facts? How does the outcome of one process, e.g. the decision by AOSIS to disrupt the conference proceedings, affect other processes, e.g. negotiations among China, the US and Europe? How does one conceptualise the processes that are underway? What is the logic of these processes? How are the players in the field living the processes? Where is the emotional interest in this story? What are the cultural/social/ political pre-conceptions of the intended public for this story?

Working journalists are making assessments on all of these fronts as a matter of course when they are researching and reporting a story. What the matrix does as a methodological tool for either reviewing previous practice or planning future practice is lift journalistic decision-making beyond the intuitive level that often accompanies quotidian professional practice, and isolate it for evaluation. Is it acceptable that Callick failed to contextualise the

94 PACIFIC JOURNALISM REVIEW 21(1) 2015 
Kench and Webb research scientific debate in the larger scientific and policy debate about its interpretation? Is Morton's account of Fry as a hero pitching to an emotional response from a particular audience that romanticises his role and the plight of the threatened islands? Is there a David vs Goliath trope to Morton's reportage that distracted from the main game in the Copenhagen summit? Is the 'cargo cult' trope a relevant conceptual framework, and is it any more or less adequate than 'heroes and villains'?

Readers of Morton, Callick and this article will make their own responses to these questions: the point of this analysis is that it demonstrates that journalism can be evaluated for its adequacy by a rich engagement with theory and methodology that goes far beyond touchstones of fairness, balance and objectivity, whatever those terms might mean in any given situation. Of course, not all journalism is going to be explicit in this theoretical engagement, just as the professional vernacular practice of medicine or law or engineering is an application of professionally (and theoretically) validated procedures without explicit reference to the underpinning theory; but the fact that those procedures are amenable to theoretical exposition and interrogation is what makes them disciplines, and likewise for journalism.

What the matrix does not do methodologically is prescribe which particular theory should be applied in any of the given elements of the framework. For example, there are a range of disciplinary and scientific theories that apply to specific aspects of climate change processes and outcomes; there are contesting social and economic theories about how a community or an economy might be affected by the dislocation of climate change and what might be the most appropriate remedies, if any. In short, the matrix is not a theory in itself, but a framework for identifying the sorts of theory that might need to be considered in any given element of the matrix. It is a meta-theoretical framework (Lefebvre, 1991, p. 405) that foregrounds the role of theory, and for that reason performs the salutary role for journalism research of explicating that it is indeed a 'theoretic' activity, as Tuchman put it.

To conclude, I would suggest that firstly, following Tuchman, spatio-temporality is a very rich methodological framework for interrogating the adequacy of journalistic truth claims. Secondly, that the Harvey-Lefebvre matrix offers a valuable meta-theoretical tool for identifying the sorts of theory that need to be considered in different aspects or elements of journalistic research for specific subject matter. Thirdly, that the self-evident role of theory in this analysis makes redundant any challenge to journalism's status as a theoretic research practice: journalism has specific challenges that need to be addressed, specific problems that need to be solved in validating its truth claims, and these challenges relate in large part to the spatio-temporality of its practice (Nash, 2014). Fourthly, the explicit spatio-temporalities of climate change as a physical and social phenomenon and the geography of the Pacific island societies have made the journalism on this topic a very fertile one for making this argument. This point illustrates the levels at which inter-disciplinarity can and must operate for journalism to be a successful form of 
POLITICAL JOURNALISM IN THE ASIA-PACIFIC

research practice: the spatio-temporalities of journalism practice have to be adequate to the spatio-temporalities/ geographies of the subject matter under investigation-in this case the agents, processes and results of climate change, and the agents, processes and results of Pacific Island responses to its challenges.

\section{References}

al-Jazeera, (2014). IPCC: Effects of climate change 'worse than we had predicted'. Retrieved on March 16, 2015, from http://america.aljazeera.com/articles/2014/3/30/ipcc-climate-changeglobalwarmingimpacts.html

Barnett, J., \& Campbell, J. (2010). Climate change and small island states: Power, knowledge and the South Pacific. London, UK: Earthscan.

Bourdieu, P. (1977). Outline of a theory of practice. Cambridge, UK: Cambridge University Press.

Bourdieu, P. (1990). The Logic of Practice. Cambridge, UK: Polity Press

Callick, R. (2009, December 12). Strange climate of neglect. The Australian.

Callick, R. (2009a, June 4). Pacific Islands growing not sinking. The Australian.

Callick. R. (2009b, June 11). Coral Islands left high and dry. The Australian.

Cameron, F. (2011). Saving the 'disappearing islands': Climate change governance, Pacific island states and cosmopolitan dispositions. Continuum, 25(6), 873-886.

Chambers, K., \& Chambers, A. (2001). Unity of heart. Culture and change in a Polynesian society. Prospect Heights, Illinois: Waveland Press

Chubb, P., \& Bacon, W. (2010). Australia: Fiery politics and extreme events. In E. Eide, R. Kunelius, \& V. Kumpu (Eds.), Global climate - local journalisms: A transnational study of how media make sense of climate summits (pp. 51-66). Global Journalism Research Series Vol. 3. Freiburg, Germany: Projekt Verlag.

Connell, J. (2003). Losing ground? Tuvalu, the greenhouse effect and the garbage can. Asia Pacific Viewpoint, 44(2), 89-107.

Farbotko, C. (2005). Tuvalu and climate change: Constructions of environmental displacement in the Sydney Morning Herald. Geografiska Annaler. Series B, Human Geography, Special Issue: Islands: Objects of Representation, 87(4), 279-293.

Farbotko, C. (2010a). 'The global warming clock is ticking so see these places while you can': Voyeuristic tourism and model environmental citizens on Tuvalu's disappearing islands. Singapore Journal of Tropical Geography, 31, 224-238.

Farbotko, C. (2010b). Wishful sinking: Disappearing islands, climate refugees and cosmopolitan experimentation. Asia Pacific Viewpoint, 51(1), 47-60.

Farbotko, C. and H. McGregor (2010). Copenhagen, Climate Science and the Emotional Geographies of Climate Change. Australian Geographer, 41(2), pp. 159-166

Harvey, D. (2009 [1973]). Social justice and the city. London, Georgia: University Of Georgia Press. Harvey, D. (2006). Spaces of global capitalism. London, UK: Verso

Intergovernmental Panel on Climate Change, 2014: IPPC Fifth Assessment Report. Retrieved on March 16,2015, from www.ipcc.ch/publications_and_data/publications_and_data_reports.shtml Intergovernmental Panel on Climate Change (2014). Climate change 2014: Synthesis report: Summary for policymakers. Retrieved on March 16, 2015, from www.ipcc.ch/pdf/assessmentreport/ar5/syr/SYR_AR5_SPM_Final.pdf

Komai, M. (2010, June 7). Pacific Island 'growing not sinking' report criticised. Pacnews.

96 PACIFIC JOURNALISM REVIEW 21(1) 2015 
Kaplan, M. (1995). Neither cargo nor cult: ritual politics and the colonial imagination in Fiji. Durham, NC: Duke University Press.

Maiden, S. (2009, December 16). Long way to beach for man of tears. The Australian.

McIntosh, A. (2009, December 16) The Oz: how low can you go? Crikey.

Morton, A. (2009a, November 21). As the globe warms up, a way of life is washed away, The Age.

Morton, A. (2009b, December 11). Small voice with big voice and bigger problem, The Age.

Morton, A. (2009c, December 12). China pours cold water on deal as tempers flare, The Age.

Morton, A. (2009d, December 13). Cry the beloved country, The Age.

Morton, A. (2009e, December 14). Wanted (badly): US and China to get along, The Age.

Morton, A (2009f, December 16). Rich poor deal threatens real deal, The Age.

Morton, A. (2009g, December 20). Copenhagen chaos as talks fail, The Sunday Age.

Morton, A. (2010, March 27). Climate can-do in Cancun, The Age.

Nash, C. and Bacon, W. (2013). 'That sinking feeling': Climate change, journalism and small island states. In Lester, L. and Hutchins, B. (Eds.), Environmental Conflict and the Media (pp. 246-259). New York, NY: Peter Lang.

Pouwer, J. (1958). Cargo cults. Oceania, 28(3), 247-252.

Ryan, Y. (2010). COP15 and Pacific island states: a collective voice on climate change. Pacific Journalism Review, 16(1), 193-203.

Schaefer, M., \& Hare, B. (2010). Persistence of atoll islands under recent and projected sea-level rise, Climate Analytics. Retrieved on March 6, 2015, from www.climateanalytics.org/sites/ default/files/attachments/publications/20100802_AtollIslandsFormationandPersistence.pdf

Tuchman, G. (1978). Making news: A study in the construction of reality. New York, NY: Free Press.

UNFCC. (2009). Retrieved on March 16, 2015, from http://unfccc.int/meetings/copenhagen dec_2009/meeting/6295.php

Webb, A., \& Kench, P.S. (2010). The dynamic reef response to sea-level rise: evidence from multi-decadal analysis of island change in the Central Pacific. Global and Planetary Change, 72(3), 234-246.

Dr Chris Nash is foundation professor of journalism at Monash University in Melbourne, Australia, and is on the editorial board of Pacific Journalism Review and a frequent contributor to the research journal. An earlier version of this article was presented at the 'Political journalism in the Asia-Pacific' PJR2014 conference at Auckland University of Technology, Auckland, on 27-29 November 2014.

chris.nash@monash.edu 